BARBARA JANKOWIAK ANNA GULCZYŃSKA

Uniwersytet im. Adama Mickiewicza w Poznaniu

\title{
EDUKACJA SEKSUALNA W SOCJOTERAPII
}

\begin{abstract}
Jankowiak Barbara, Gulczyńska Anna, Edukacja seksualna w socjoterapii [Sexual education in sociotherapy]. „Neodidagmata” 35, Poznań 2013, Adam Mickiewicz University Press, pp. 21-32. ISBN 978-83-232-2685-7. ISSN 0077-653X.
\end{abstract}

The author analyzes seven main models (paradigms, patterns) of reflecting on educational reform. According to the assumptions adopted in the literature, sociotherapy is also provided as a therapeutic means of achieving educational targets. It seems that the educational and developmental nature of such interaction is particularly important in this psychological and pedagogical field because of the group to which this kind of assistance is provided. Children and young people constitute target groups of socio-therapeutic activities, which is why it is extremely important to deal with issues related to their psychosexual functioning. Sexuality is an essential attribute of every human being although it seems to be a problem for many adults - both parents and teachers. The idea of this paper is to indicate the importance of addressing the appropriate issues connected with sex education in socio-therapeutic activities.

Barbara Jankowiak, Uniwersytet im. Adama Mickiewicza w Poznaniu, Wydział Studiów Edukacyjnych, Zakład Promocji Zdrowia i Psychoterapii, ul. Szamarzewskiego 89, 60-568 Poznań, Polska-Poland.

Anna Gulczyńska, Uniwersytet im. Adama Mickiewicza w Poznaniu, Wydział Studiów Edukacyjnych, Pracownia Edukacji Zdrowotnej, ul. Szamarzewskiego 89, 60-568 Poznań, Polska - Poland.

Na początku przedstawiono sposób rozumienia socjoterapii. Wydaje się to szczególnie istotne, gdyż zarówno w literaturze, jak i w praktyce podejmowania działań socjoterapeutycznych brak jednoznacznego definiowania tej formy pomocy. Następnie wskazano, jaki sposób ujmowania zagadnień z obszaru edukacji seksualnej może być przydatny i możliwy w trakcie realizacji zajęć socjoterapeutycznych. $W$ tej części pracy podjęto starania, aby wykazać, że edukacja seksualna powinna mieć miejsce w planowanych oddziaływaniach pomocowych. 
W niniejszym opracowaniu przyjęto następującą definicję socjoterapii:

[...] formy pomocy psychopedagogicznej ukierunkowanej na dzieci i młodzież z grup ryzyka lub/i przejawiających zaburzenia w funkcjonowaniu psychospołecznym, która polega na intencjonalnym uruchamianiu czynników pomocowych, wykorzystujących procesy grupowe i rolę socjoterapeuty, w celu kompensacji potencjalnych deficytów rozwoju społecznego i zapobieganiu kształtowania się zaburzeń uczestników grupy (Jankowiak, Soroko, 2013).

Definicji edukacji seksualnej, począwszy od lat 60., powstało wiele. Eksperci Światowego Stowarzyszenia na rzecz Zdrowia Seksualnego edukację seksualną traktują jako "naukę o poznawczych, emocjonalnych, społecznych, interaktywnych i fizycznych aspektach seksualności" <http://www. undp.org.pl/content/download/1687/9214/file/WHO_BZgA_Standardy_ edukacji_seksualnej.pdf $>$.

Z kolei w publikacji International Technical Guidance on Sexuality Education <http:/ / unesdoc.unesco.org/ images/0018/001832/183281e.pdf>:

[...] edukacji seksualna jest definiowana jako dostosowany do wieku i kultury sposób nauczania o płci i związkach, dostarczający dokładnych, realistycznych i nieosadzających informacji. Edukacja seksualna zapewnia możliwość „badania” własnych wartości i postaw, umożliwia zdobycie umiejętności podejmowania decyzji, komunikowania się i zmniejszenia ryzyka w odniesieniu do wielu aspektów seksualności.

Coraz częściej w publikacjach naukowych <http://ippf.org/our-work/ what-we-do/adolescents/education> pojawia się termin „wszechstronna edukacja seksualna" (CSE), odnoszący się do opartej na prawie i równości płci edukacji o seksualności, płciowości, zdrowiu seksualnym i reprodukcyjnym oraz zachowaniach seksualnych. Tak ujmowana edukacja seksualna wyposażać ma młodych ludzi w umiejętności życiowe, dzięki którym będą podejmowali autonomiczne decyzje w obszarze seksualności.

Takie rozumienie podstawowych dla tematu pracy pojęć wskazuje kilka istotnych dla praktyki pomocowej implikacji. Poniżej odniesiono się do niektórych z nich - ważnych ze względu na podejmowanie kwestii edukacji seksualnej.

Po pierwsze, istotne jest wykazanie znaczenia przekazywania wiedzy (a więc realizacji celów edukacyjnych) w tej formie pomocy psychologiczno-pedagogicznej. Właśnie oddziaływania edukacyjne sprzyjają możliwości zaistnienia specyficznych dla socjoterapii czynników pomocowych. W pracy (Jankowiak, Soroko, w druku) wykazano znaczenie i możliwość zaistnienia czynników terapeutycznych wymienianych przez autorów, charakteryzujących inne formy psychologicznej pomocy grupowej (Yalom, Leszcz, 2006; Vinogradov, Yalom, 2007; Cierpiałkowska, Czabała, 2005; Corey, Corey, 2008) $\mathrm{i}$ ich znaczenie $\mathrm{w}$ socjoterapii. 
Jednym z czynników terapeutycznych wymienianych przez Yaloma (2006), klasyka psychoterapii grupowej, praktyka i badacza procesu terapii grupowej, jest udzielanie informacji. Ranga tego komponentu uwidacznia się także w przypadku grup socjoterapeutycznych, w których psychoedukacja jest istotnym elementem pracy z dziećmi i młodzieżą. Socjoterapeuci przekazują informacje na temat różnych kwestii psychospołecznych $\mathrm{w}$ tym także - co dla tej pracy szczególnie istotne - informacji z zakresu seksualności. Przekazywanie wiedzy odbiorcom grup socjoterapeutycznych zapewnić ma wyposażenie ich w odpowiedni, profesjonalny i prawdziwy naukowo zasób informacji, stanowiący ważny komponent w rozwoju umiejętności i kształtowaniu postaw sprzyjających dbałości o zdrowie seksualne. Dobór tematów, a zatem zakresu przekazywanej wiedzy wynika z okresu rozwojowego adresata pomocy, a znajduje odzwierciedlanie między innymi w opisanym niżej rozporządzeniu ministra edukacji narodowej. Udzielanie informacji odnosi się najczęściej do sytuacji, kiedy dzieci i młodzież pytają o pewne kwestie, które nie zostały, w ich poczuciu, odpowiednio omówione lub co do których mają obawy i wątpliwości. Z analizy dostępnych badań wynika istnienie sprecyzowanych oczekiwań społecznych dotyczących edukowania dzieci i młodzieży na temat płciowości oraz że nie tylko rodzice powinni przekazywać tego typu informacje. Zgodnie z wynikami opublikowanymi przez CBOS <http://www.cbos.pl/SPISKOM. POL/2007/ K_123_07.PDF> niemal 3/5 ankietowanych (59\%) jest zdania, że obowiązek przekazywania dzieciom wiedzy o życiu seksualnym człowieka spoczywa w równym stopniu na rodzicach i na szkole, 1/3 zaś (34\%) sądzi, że należy on przede wszystkim do rodziców. Uczestnicy zajęć socjoterapeutycznych w większości wywodzą się ze środowisk dysfaworyzowanych kulturowo (Sawicka, 2006). Dlatego przypuszcza się, że poziom komunikowania $\mathrm{w}$ tych rodzinach jest również utrudniony $\mathrm{w}$ zakresie tematów związanych z seksualnością. Dzieci i młodzież doświadczać mogą chaosu oraz dezinformacji dotyczącej normy i patologii seksualnej, zachowań preferowanych czy podejmowanych $\mathrm{w}$ ich środowiskach, a obowiązujących $\mathrm{w}$ tych wyrażonych w normach współżycia społecznego. Dlatego tak ważne jest zarówno przekazywanie wiedzy, jak i udzielanie profesjonalnych informacji uczestnikom grup socjoterapeutycznych.

Prowadzone były także badania dotyczące źródeł wiedzy młodzieży na temat seksualności człowieka. Zgodnie $\mathrm{z}$ wynikami, uzyskanymi na reprezentatywnej próbie młodzieży <http:/ / www.swiadomerodzicielstwo.com/ index.php/okampani/cbos>, głównym źródłem wiedzy o zachowaniach seksualnych są dla nich: rówieśnicy (koledzy) - 55,4\%, Internet - 43,9\%, szkoła i nauczyciele - 34,9\%, czasopisma młodzieżowe - 32,6\%. Powyższe dane świadczą o kilku faktach. Po pierwsze, młodzież nie ma dostępu do 
rzetelnej oraz dostosowanej do ich potrzeb rozwojowych wiedzy. Po drugie, wysoką rangę przypisuje rówieśnikom, co wynikać może ze swobody $\mathrm{w}$ wypowiadaniu się $\mathrm{w}$ kwestiach intymnych $\mathrm{w}$ takiej grupie. Powyższe konkluzje wydają się szczególnie istotne w kontekście socjoterapii uwzględniającej podobny wiek rozwojowy uczestników grup, a co się z tym wiąże - przekazywanie adekwatnych treści $\mathrm{w}$ interakcji dorosłego z dziećmi i młodzieżą oraz interakcjach międzyrówieśniczych. Co więcej, młodzi ludzie uważają, że informacje o seksualności powinni im dostarczać rodzice - 72,9\%, szkoła - 61,6\% czy lekarz lub farmaceuta - 35,7\%, a więc osoby dorosłe, których znajomość tematu wykracza poza wiedzę posiadaną przez rówieśników. Jak wynika z cytowanych wcześniej badań, dorośli nie spełniają pokładanych $\mathrm{w}$ nich oczekiwań. Korespondujące $\mathrm{z}$ przytaczanymi danymi są kolejne analizy. Mianowicie, rodzice często nie są do tych zadań edukacyjnych odpowiednio przygotowani, stąd nie dziwi fakt, że $20 \%$ badanej młodzieży nie ma w swojej rodzinie osoby, z którą mogliby porozmawiać o sprawach seksu <http:// ponton.org.pl/sites/ponton/files/raport_ skad_wiesz_grupa_ponton_2011.pdf>. Przytoczone powyżej badania przeprowadzone zostały na reprezentatywnej próbie respondentów. Nie dotyczą one bezpośrednio dzieci i młodzieży uczęszczającej na socjoterapię, pokazują jedynie pewne tendencje $\mathrm{w}$ polskim społeczeństwie. Być może warto byłoby zbadać, czy, a jeśli tak, to w jaki sposób, informacje z zakresu seksualności przekazywane są przez rodziców czy opiekunów, odbiorców zajęć socjoterapeutycznych.

Należy zaznaczyć, że w pracy z dziećmi i młodzieżą dużo większą wagę przykłada się do przekazywania konkretnych informacji umożliwiających podejmowanie decyzji życiowych niż $\mathrm{w}$ pracy $\mathrm{z}$ osobami dorosłymi. Dane z raportu Pontonu <http:// ponton.org.pl/sites/ponton/files/raport_jaka_ edukacja_seksualna_grupa_ponton_2009.pdf > świadczą o zapotrzebowaniu młodzieży na takie konkretne informacje, $\mathrm{w}$ tym: dojrzewanie dziewcząt i chłopców, profilaktykę chorób przenoszonych drogą płciową, nowoczesne środki antykoncepcyjne, prewencję przemocy seksualnej, wiedzę o asertywności i orientacjach seksualnych. Potwierdzają to wyniki pochodzące ze wspomnianych badań CBOS - 79,9\% młodych respondentów uważa, że brak wiedzy na temat życia seksualnego i środków antykoncepcyjnych jest główną przyczyną przypadkowych ciąż nastolatek.

O tym, iż należy edukować dzieci o wszystkich konsekwencjach wynikających z faktu, iż są istotami seksualnymi, płciowymi oraz że inni też mają te atrybuty, stanowią liczne akty prawne, rozporządzenia - krajowe oraz zagraniczne. Aktualne i dokładne ich zestawienie zaleźć można w pracy Kasperek-Golimowskiej (2012). Polscy urzędnicy, podpisując liczne dokumenty - zarówno wewnętrzne, jak i międzynarodowe, zgodzili się 
w imieniu całego społeczeństwa, zapewnić dostęp do pełnej i rzetelnej wiedzy z zakresu edukacji seksualnej.

Innym czynnikiem pomocowym w socjoterapii jest przekazywanie wartości (Jankowiak, Soroko, w druku). Kształtowanie określonego systemu wartości wydaje się niezwykle istotne $\mathrm{w}$ kontekście szacunku dla drugiego człowieka, dla własnego ciała oraz w tworzeniu związków interpersonalnych. Kwestie te są ważnym elementem szeroko rozumianej edukacji seksualnej. Warto zauważyć, że wiele osób ma trudności z samym stwierdzeniem: edukacja seksualna, ponieważ dotyczy ono strefy intymnej, w której ludzie mają wiele własnych doświadczeń, osobistych kompleksów czy uprzedzeń. Rodzice mogą niejednoznacznie oceniać potrzebę edukacji seksualnej ich dzieci w takich instytucjach, jak szkoły, świetlice socjoterapeutyczne czy innego typu placówki opiekuńczo-wychowawcze ze względu na lęk przed niewłaściwym przekazywaniem treści związanych z płciowością. Obawy zazwyczaj dotyczą przekazywania "technicznych" informacji dotyczących seksualności zamiast kształtowania odpowiednich wartości i norm $\mathrm{w}$ interakcjach międzyludzkich. Lęk wzmagają pseudonaukowe stwierdzenia, coraz bardziej popularne $\mathrm{w}$ internetowych serwisach informacyjnych czy prasie. Większość rodziców i wychowawców chce, aby dzieci i młodzież uczyły się o szacunku dla samych siebie, własnego ciała, o tym, co robić, kiedy ktoś chce ich skrzywdzić, a także o szacunku dla innych ludzi i ich wyborów. Potwierdzają to wyniki badań <http://www.edulandia.pl/ edukacja/1,112291,9109417,O_ czym_chca_rozmawiac_gimnazjalisci_a_o_ czym_rodzice_html>, zgodnie z którymi $89 \%$ rodziców chce, aby gimnazjaliści na lekcjach $\mathrm{z}$ wychowania do życia w rodzinie uczyli się o zakładaniu rodziny i życiu w niej, a także o szacunku do samego siebie.

Obserwując przemiany seksualności we współczesnym świecie - opisywane w literaturze przedmiotu zarówno polskiej (Gulczyńska, 2009; Grzelak, 2009; Jankowiak, 2010; Izdebski, Niemiec, Waż, 2011; Imacka, Bulsa, 2012), jak i anglojęzycznej (Pligt, Richard, 1994; Kershaw i in., 2004; Scott-Sheldon i in., 2010), śledząc także aktualne badania społeczne <www.swiadomerodzicielstwo.com>, należy zastanawiać się nie nad tym, czy mówić o seksualności, w jaki sposób przekazywać dzieciom i młodzieży wartości związane z seksualnością. Niezależnie bowiem od tego, czy jednostka zgadza się na to, czy nie, seks epatuje z telewizji, reklam i billbordów, jest nim przepełniony Internet. Młody człowiek żyje zatem i kształtuje swoją tożsamość $\mathrm{w}$ pewnym chaosie - zarówno informacyjnym, jak i na poziomie wartości. Potrzebuje dorosłych, którzy, odpowiednio przygotowani, będą $\mathrm{w}$ stanie sprostać trudnym tematom danego etapu rozwojowego. Dlatego w okresie, kiedy jest czas na to, a więc w okresie szkolnym, warto uczyć dzieci o seksualności i płciowości w szerokim zakresie. 
Podsumowując, zarówno przekazywanie wiedzy i informacji, jak i przekazywanie wartości można analizować jako zjawiska charakterystyczne dla podejmowania określonej interwencji wychowawczej (Jankowiak, Soroko, w druku). Zdaniem Brzezińskiej (2000, s. 234): „interwencja wychowawcza (edukacyjna) skierowana na osoby oznacza podjęcie działań zmierzających do wywołania zmian w ich umiejętnościach, wiedzy, postawach, wartościach". Podjęcie takiego sposobu interpretacji wskazuje, że w działaniach socjoterapeutycznych przeplatają się zarówno zjawiska charakterystyczne dla psychoedukacji, psychoterapii, jak i te typowe dla pedagogiki i wychowania (Jankowiak, Soroko, w druku).

Po drugie, ta forma pomocy skierowana jest do dzieci i młodzieży. Wskazuje to na ogromne znaczenie realizacji celów rozwojowych. Oddziaływania pomocowe należy bowiem dostosować do aktualnych możliwości i potrzeb wybranej grupy.

W tym kontekście niezwykle istotną kwestią jest kwalifikacja do grup socjoterapeutycznych. Inne bowiem problemy i możliwości rozumienia mają na przykład adolescenci, a inne dzieci w wieku wczesnoszkolnym. W przypadku poruszania treści dotyczących seksualności człowieka staranność w doborze grupy nabiera dodatkowego znaczenia. Odmienne problemy rozwoju psychoseksualnego dotyczą dzieci i młodzieży w różnym wieku oraz charakteryzują ich różne możliwości poznawcze i emocjonalne.

Pewną pomocą dla osób realizujących tematykę z zakresu seksualności może być rozporządzenie ministra edukacji narodowej z dnia 23 grudnia 2008 r. Określa ono bardzo szczegółowo dobrany do danego etapu rozwoju zakres tematyczny <http://bip.men.gov.pl/men_bip/akty_prawne/rozpo rzadzenie_20081223_zal_4.pdf>. Ważne jest, aby pamiętać, że przytoczone niżej wytyczne stanowią pewną podpowiedź dla prowadzących grupy, zasadniczą kwestią $\mathrm{w}$ doborze tematów są oczekiwania i potrzeby uczestników socjoterapii. Dla klas 4-6 proponuje się następujące zagadnienia:

1. Podstawowe funkcje rodziny $\mathrm{z}$ podkreśleniem miejsca dziecka $\mathrm{w}$ rodzinie.

2. Przekaz wartości i tradycji w rodzinie, wspólne świętowanie, spędzanie wolnego czasu.

3. Więź rodzinna, związki uczuciowe i inne relacje w rodzinie; konflikty $\mathrm{i}$ ich rozwiązywanie.

4. Macierzyństwo i ojcostwo; podstawowa wiedza dotycząca budowy i funkcjonowania układu rozrodczego człowieka.

5. Ciąża, rozwój płodu, poród, przyjęcie dziecka jako nowego członka rodziny.

6. Różnice i podobieństwa między chłopcami i dziewczętami; identyfikacja z własną płcią; akceptacja i szacunek dla ciała. 
7. Zmiany fizyczne i psychiczne okresu dojrzewania; zróżnicowane, indywidualne tempo rozwoju.

8. Higiena okresu dojrzewania.

9. Prawo człowieka do intymności i ochrona tego prawa; postawy asertywne.

10. Istota koleżeństwa i przyjaźni, wzajemny szacunek, udzielanie sobie pomocy, współpraca, empatia.

11. Mass media - zasady i kryteria wyboru czasopism, książek, filmów i programów telewizyjnych.

12. Instytucje działające na rzecz dziecka i rodziny.

13. Odpowiedzialność za własny rozwój; samowychowanie.

Treści proponowane dla gimnazjum są następujące:

1. Rozwój człowieka: faza prenatalna, narodziny, faza niemowlęca, wczesnodziecięca, przedpokwitaniowa, dojrzewania, młodości, wieku średniego, wieku późnego. Życie jako fundamentalna wartość.

2. Budowa prawidłowych relacji z rodzicami. Konflikt pokoleń; przyczyny i sposoby rozwiązywania konfliktów. Odpowiedzialność wszystkich za atmosferę panującą $\mathrm{w}$ rodzinie. Rodzina niepełna.

3. Rola autorytetów w życiu człowieka.

4. Relacje międzyosobowe i ich znaczenie. Przyjaźń, zakochanie, miłość; pierwsze fascynacje, miłość platoniczna, miłość młodzieńcza, miłość dojrzała.

5. Zachowania asertywne.

6. Podstawowe informacje o rozwoju seksualnym człowieka: tożsamość płciowa: kobiecość i męskość.

7. Dojrzewanie. Rozumienie i akceptacja kryteriów dojrzałości biologicznej, psychicznej i społecznej.

8. Problemy i trudności okresu dojrzewania (napięcia seksualne, masturbacja), sposoby radzenia sobie $\mathrm{z}$ nimi, pomoc $\mathrm{w}$ rozeznaniu sytuacji wymagających porady lekarza lub innych specjalistów.

9. Różnice w rozwoju psychoseksualnym dziewcząt i chłopców; postawy i wzajemne oczekiwania.

10. Zagrożenia okresu dojrzewania: presja seksualna, uzależnienia, pornografia, prostytucja nieletnich.

11. Główne funkcje płciowości: wyrażanie miłości, budowanie więzi i rodzicielstwo.

12. Inicjacja seksualna; związek pomiędzy aktywnością seksualną a miłością i odpowiedzialnością; dysfunkcje związane z przedmiotowym traktowaniem człowieka w dziedzinie seksualnej. Ryzyko związane z wczesną inicjacją. 
13. Kształtowanie i akceptacja tożsamości płciowej. Możliwości pomocy w pokonywaniu trudności związanych z tożsamością płciową.

14. Płodność wspólną sprawą kobiety i mężczyzny.

15. Planowanie rodziny. Metody rozpoznawania płodności. Antykoncepcja - aspekt zdrowotny, psychologiczny i etyczny.

16. Infekcje przenoszone drogą płciową. AIDS: drogi przenoszenia zakażenia, profilaktyka, aspekt społeczny.

17. Wartości związane z seksualnością człowieka: męskość, kobiecość, miłość, małżeństwo, rodzicielstwo. Znaczenie odpowiedzialności w przeżywaniu własnej płciowości oraz budowaniu trwałych i szczęśliwych więzi.

18. Wpływ sposobu spędzania wolnego czasu (w tym korzystania ze środków masowego przekazu) na człowieka.

Podsumowując, omawiane $\mathrm{w}$ literaturze przedmiotu czynniki terapeutyczne, występujące $\mathrm{w}$ grupowych formach pomocy, warto zauważyć, że odwołują się one $\mathrm{w}$ dużej mierze do kwestii rozwojowych uczestników grup. Należą do nich: rozwój umiejętności społecznych (Yaloma, 2006), towarzyszenie w przeżywaniu kryzysów rozwojowych, identyfikacja z pozytywnym dorostym (Jankowiak, Soroko, w druku). Intencjonalne wprowadzanie tych czynników pomocowych jest istotne, ponieważ dzieci i młodzież uczęszczająca na socjoterapię z całą pewnością będzie przeżywać w jej trakcie kryzysy rozwojowe związane z podejmowaniem kolejnych zadań rozwojowych oraz z przechodzeniem przez fazy rozwoju psychospołecznego i psychoseksualnego (por. Erikson, 2000; Brzezińska, 2004). W niniejszej pracy skoncentrowano się na znaczeniu wątków psychoseksualnych ważnych w procesie rozwoju uczestników grup.

Po trzecie, socjoterapia ma na celu kompensacje potencjalnych deficytów rozwoju społecznego i zapobieganie kształtowaniu się zaburzeń uczestników grupy. Takiemu podejściu sprzyja grupowa forma spotkań. Odwołując się do psychoterapii grupowej dzieci i młodzieży, bliskiej - ze względu na formę i grupę docelową - socjoterapii, można zacytować zdanie Kendalla, iż „wzmocnienie ze strony rówieśników i grupy jest często bardziej efektywne $u$ dzieci niż wzmocnienie dostarczone $w$ sytuacji diady albo przez dorosłych" (Kendall, 2000, s. 59, za: Zalewska, Schier, 2006).

Znaczenie właściwego funkcjonowania międzyludzkiego w odniesieniu do realizacji własnej płciowości jest niezwykle istotne i podkreślane zarówno w normatywnym ujęciu seksualności (Imieliński, 1988), jak i wyrażane poprzez oczekiwania społeczne rodziców, wychowawców i nauczycieli a więc osób kierujących dzieci i młodzież na zajęcia socjoterapeutyczne.

Biorąc pod uwagę założenia socjoterapii - a więc formy pomocy psychopedagogicznej mającej na celu korekcję deficytów funkcjonowania społecznego - temat społecznego funkcjonowania w obszarze seksualności uczestników grup nie może być pominięty. 
Zapotrzebowanie społeczne $\mathrm{w}$ tej kwestii wynika, w dużej mierze, z opisywanych przez media, szokujących opinię publiczną, zachowań seksualnych dzieci i młodzieży. Nagłaśniane są przypadki zabaw seksualnych gimnazjalistów, które zagrażają ich życiu i zdrowiu - jak chociażby „słoneczko" lub "pociąg" - czyli formy seksu grupowego gimnazjalistów <http:/ / www.fakt.pl / Zabawa-w-sloneczko-jest-juz-niemodne-Teraz-rzadzi-lokomo tywa,artykuly,138267,1.html>. Popularna stała się także gra „wymiękasz?”, czyli dotykanie miejsc intymnych wylosowanej osoby. Dobrze znana "butelka" polega obecnie na tym, że całowanie zostało zastąpione seksem oralnym lub zwykłym stosunkiem. <http://wiadomosci.gazeta.pl/wiadomosci/ 1,126765,10122474,Szokujace_seksualne_zabawy_gimnazjalistow__modne. html>.

Wynika $\mathrm{z}$ tego, że młodzież biorąca udział $\mathrm{w}$ tego typu zabawach nie zdaje sobie sprawy z konsekwencji, które dotyczyć mogą nie tylko niechcianej ciąży, ale także chorób przenoszonych drogą płciową. W takiej sytuacji rola edukacji seksualnej jest ogromna.

Komunikaty medialne zawierają również opis agresywnych zabaw adolescentów, łamiących nie tylko normy społeczne, ale także mających znamiona czynów przestępczych. Przykładem może być pięciu uczniów Gimnazjum nr 2 w Gdańsku, którzy w 2006 r. molestowali swoją koleżankę 14-letnią Anię. Dzień później dziewczynka popełniła w domu samobójstwo. Dzień przed śmiercią samobójczą Ani uczniowie zdjęli jej spodnie i majtki, dotykali po całym ciele, w szczególności w miejscach intymnych, oraz pozorowali akt seksualny. Jeden z napastników nagrywał to wszystko na telefon komórkowy, gdyż działo się to w szkolnej klasie <http://wiadomo sci.gazeta.pl/wiadomosci/1,126765,9195980,Rozebrali_macali_az_popelnila_ samobojstwo_Oprawcy.html>. Coraz częściej pojawiają się również doniesienia na temat gwałtów w szkołach. Jak wynika z danych Komendy Głównej Policji, w 2012 r. w placówkach edukacyjnych odnotowano aż 74 gwałty, czyli o 60 więcej niż w roku wcześniejszym <http://www.rp.pl/artykul/ 980983.html>.

Wydaje się, że w takich przypadkach zabrakło nie tylko przekazywania odpowiednich informacji na temat seksualności, ale przede wszystkim ukształtowania systemu wartości, w którym wrażliwość, empatia oraz szacunek dla drugiego człowieka i jego cielesności miałyby istotne znaczenia. Być może wynikiem tych, a także innych analiz jest ogłoszenie przez minister Szumilas roku 2013 rokiem bezpiecznej szkoły <http:/ /www.men.gov. $\mathrm{pl} /$ index.php?option $=$ com_content\&view $=$ article\&id $=3931 \% 3$ Alist-krystynyszumilas-ministra-edukacji-narodowej-z-okazji-midzynarodowego-dnia-bez piecznego-internetu\&catid=29\%3Aministerstwo-pozostae-wydarzenia-eduka cyjne\&Itemid $=53>$. 
Celem pracy było zaprezentowanie, $\mathrm{w}$ jaki sposób treści z zakresu edukacji seksualnej mogá celowo zostać zaadaptowane $\mathrm{w}$ proces socjoterapii. Podjęto starania, aby wykazać znaczenie wszechstronnej edukacji seksualnej w rozwoju dzieci i młodzieży oraz możliwość jej zastosowania w formie pomocy psychologiczno-pedagogicznej. Wydaje się to niezwykle istotne ze względu na cele socjoterapii - edukacyjne oraz rozwojowe. Zgodnie z założeniami Biura Regionalnego Światowej Organizacji Zdrowia (WHO) dla Europy oraz Federalnego Biura ds. Edukacji Zdrowotnej w Kolonii, opublikowanymi w Polsce w kwietniu 2013 r. <http://www.undp.org.pl/content/ download/1687/9214/file/WHO_BZgA_Standardy_edukacji_seksualnej.pdf>, młodzież potrzebuje zarówno formalnej, jak i nieformalnej edukacji seksualnej. Ta pierwsza ma miejsce zazwyczaj w szkołach oraz innych instytucjach opiekuńczych i wychowawczych. Jej konieczność uwarunkowana jest nie tylko potrzebami rozwojowymi, ale także licznymi przemianami społecznymi. Z jednej strony globalizacja i jej symbol - Internet, niosący możliwość dostępu do, często niebezpiecznej dla młodego człowieka, wiedzy oraz kształtujący pewne postawy wobec seksualności, z drugiej - rozpowszechnianie się chorób przenoszonych drogą płciową czy wykorzystywanie seksualne nieletnich stawiają przed edukatorami seksualnymi trudne wyzwania, wymagające stworzenia odpowiednich programów. Owa formalna edukacja, której podlegają dzieci i młodzież, daje szerokie możliwości oddziaływań - profilaktycznych i prewencyjnych. Dzięki odpowiedniemu jej prowadzeniu możliwym staje się również korygowanie powstałych, podczas nieformalnej edukacji, fałszywych sądów i opinii. Szczególnie w grupie osób, które zakwalifikowane zostały na zajęcia socjoterapeutyczne, wydaje się stanowić to kwestie szczególnie ważne. Podsumowując, przytoczyć można następujący cytat:

Edukacja seksualna powinna być zawsze dostosowana do różnych grup wiekowych znajdujących się na różnych poziomach społecznych, ponieważ odnosi się do seksualności, która ma kluczowe znaczenie w życiu człowieka. Znaczną uwagę należy poświęcić młodzieży zagrożonej wykluczeniem, takiej jak emigranci, mniejszości seksualne, osoby niepełnosprawne, a także osoby, które nie przeszły edukacji na dostatecznym poziomie (Biuro Regionalne Światowej Organizacji Zdrowia (WHO) dla Europy oraz Federalne Biuro ds. Edukacji Zdrowotnej w Kolonii; <http:// www.undp.org.pl/content/download/1687/9214/file/WHO_BZgA_Standardy_ edukacji_seksualnej.pdf>).

Celem niniejszego artykułu było wykazanie znaczenia edukacji seksualnej pracy $\mathrm{z}$ grupą $\mathrm{w}$ socjoterapii. 


\section{LITERATURA}

Brzezińska A., Psychologia wychowania, [w:] J. Strelau, Psychologia. Podręcznik akademicki, t. 3, GWP, Gdańsk 2000.

Imacka J., Bulsa M., Ryzykowne zachowania seksualne młodzieży jako czynnik zwiększajacy ryzyko zakażenia chorobami przenoszonymi droga ptciowa, „Hygeia Public Health” 2012, 47(3), s. 272-276.

Imieliński K. (red.), Seksuologia społeczna, PWN, Warszawa 1984.

Izdebski Z., Niemiec T., Wąż K., (Zbyt) Młodzi rodzice, Wyd. Trio, Warszawa 2011.

Jagieła J., Socjoterapia w szkole. Krótki poradnik psychologiczny, Wyd. Rubikon, Kraków 2009.

Jankowiak B., Aktywność seksualna nauczycieli a jakość i trwatość ich związków partnerskich, Wyd. Nauk. UAM, Poznań 2010.

Jankowiak B., Soroko E., Czynniki terapeutyczne w socjoterapii, [w:] B. Jankowiak (red.), Socjoterapia jako forma pomocy psychologiczno-pedagogicznej. Teoria i praktyka, Wyd. Nauk. UAM, Poznań 2013, s. 83-105.

Jankowiak B., Soroko E., Socjoterapia a inne formy pomocy psychologiczno-pedagogicznej, [w:] B. Jankowiak (red.), Socjoterapia jako forma pomocy psychologiczno-pedagogicznej. Teoria i praktyka, Wyd. Nauk. UAM, Poznań 2013, s. 33-59.

Gapik L., Seksuologia - zagadnienia wybrane, [w:] G. Bręborowicz (red.), Ginekologia, PZWL, Warszawa 2005.

Gulczyńska A., Rodzinne uwarunkowania aktywności seksualnej młodych dorosłych, Wyd. Nauk. UAM, Poznań 2009.

Grzelak S., Profilaktyka ryzykownych zachowań seksualnych młodzieży, Wyd. Rubikon, Kraków 2009.

Kasperek-Golimowska E., Edukacja seksualna jako forma ochrony i promocji zdrowia seksualnego, [w:] K. Waszyńska, Z. Lew-Starowicz (red.), Przemiany seksualności w społeczeństwie wspótczesnym. Teoria i rzeczywistość, Wyd. Nauk. UAM, Poznań 2012, s. 87-131.

Kershaw T.S., Ickovics J.R., Lewis J.B., Niccolai L.M., Milan S., Ethier K.A., Sexual Risk Following a Sexually Transmitted Disease Diagnosis: The More Things Change the More They Stay the Same, „Journal of Behavioral Medicine" 2004, Vol. 27, No. 5.

Pligt J., Richard R., Changing adolescents' sexual behaviour: Perceived risk, self-efficacy and anticipated regret, „Patient Education and Counseling” 1994, Vol. 23(3), s. 187-196.

Sawicka H., Socjoterapia jako forma pracy z dziećmi i młodzieża przejawiającymi zaburzone zachowania, [w:] I. Dąbrowska-Jabłońska (red.), Terapia dzieci i młodzieży. Metody i techniki pomocy psychopedagogicznej, Oficyna Wydawnicza Impuls, Kraków 2006.

Scott-Sheldon L.A.J., Fielder R.L., Carey M.P., Sexual Risk Reduction Interventions for Patients Attending Sexually Transmitted Disease Clinics in the United States: A Meta-Analytic Review, 1986 to Early 2009, "Annals of Behavioral Medicine” 2010, 40, s. 191-204.

Strzemieczny J., „Zeszyty Socjoterapeutyczne”, PTP, 1988.

Yalom I., Leszcz M., Psychoterapia grupowa. Teoria i praktyka, Wyd. Uniw. Jagiellońskiego, Kraków.

Zalewska M., Schier K., Psychoterapia dzieci i młodzieży, [w:] L. Grzesiuk (red.), Psychoterapia. Praktyka, ENETEIA Wyd. Psychologii i Kultury, Warszawa 2006.

Strony internetowe

<http://bip.men.gov.pl/men_bip/akty_prawne/rozporzadzenie_20081223_zal_4.pdf>, [dostęp: 02.03.2013]. 
<http://ponton.org.pl/sites/ponton/files/raport_skad_wiesz_grupa_ponton_2011.pdf>, [dostęp: 20.02.2013].

<http:// ponton.org.pl/sites/ponton/files/raport_jaka_edukacja_seksualna_grupa_pon ton_2009.pdf>, [dostęp: 03,01.2013].

<www.cbos.pl/SPISKOM. POL/2007/K_123_07.PDF>, [dostęp: 10.01.2013].

$<w w w . e d u l a n d i a . p l / e d u k a c j a / 1,112291,9109417, O$ _czym_chca_rozmawiac_gimnazjalis ci_a_o_czym_rodzice_html>, [dostęp: 10.02.2013].

<www.swiadomerodzicielstwo.com>, [dostęp: 20.01.2013].

<http:/ / wiadomosci.gazeta.pl/wiadomosci/1,126765,9195980,Rozebrali_macali_az_pop elnila_samobojstwo_Oprawcy.html>, [dostęp: 09.03.2013].

<http:/ / wiadomosci.gazeta.pl/wiadomosci/1,126765,10122474,Szokujace_seksualne_za bawy_gimnazjalistow_modne.htm>, [dostęp: 09.03.2013].

<http:/ / www.fakt.pl/Zabawa-w-sloneczko-jest-juz-niemodne-Teraz-rzadzi-lokomoty wa, artykuly,138267,1.html>, [dostęp dnia: 09.03.2013].

<http:/ / www.rp.pl/artykul/980983.html>, [dostęp: 03.03.2013].

<http://www.men.gov.pl/index.php?option=com_content\&view=article\&id=3931\%3Al ist-krystyny-szumilas-ministra-edukacji-narodowej-z-okazji-midzynarodowego-dnia -bezpiecznego-internetu\&catid=29\%3Aministerstwo-pozostae-wydarzenia-edukacyj ne\&Itemid=53>, [dostęp: 01.03.2013].

<http://www.undp.org.pl/content/download/1687/9214/file/WHO_BZgA_Standard y_edukacji_seksualnej.pdf>, [dostęp: 22.06.2013].

<http://unesdoc.unesco.org/ images/0018/001832/183281e.pdf>, [dostęp: 22.06.2013].

<http://ippf.org/our-work/what-we-do/adolescents/education>, [dostęp: 22.06.2013]. 